\section{Response to: 'Tapering without relapse in rheumatoid arthritis patients with high TNF blocker concentrations: data from the STRASS study' by Marotte et al}

We thank Marotte et al for their interest in our study and for presenting their own recent study. The Spacing of TNF-blocker injections in Rheumatoid ArthritiS Study (STRASS) results on drug concentrations are highly valuable, as this is a large, pragmatic, randomised trial. Marotte et al found that high drug concentrations were related to lower relapse rates after 6 months of tapering. ${ }^{1}$ This is in line with our study, where we found that patients with high adalimumab concentrations could safely reduce the dose. ${ }^{2}$

In the STRASS study, 39\% of the patients discontinued the biologic disease-modifying antirheumatic drugs (bDMARDs) successfully. ${ }^{3}$ These patients, apparently, did not need the drug anymore, suggesting that any drug concentration was too high. This might explain why Marotte et al did not find an association between drug concentrations and relapse rates at long-term follow-up. Other patients in the study did require the drug, but could achieve the same result with less of it. For this latter group, in particular, therapeutic drug monitoring (TDM) can be helpful to reduce the dose safely. However, it is currently impossible to differentiate between these two groups of patients before tapering starts.

Moreover, as Marotte et al emphasised as well, the critical tumour necrosis factor (TNF) inhibitor concentration necessary to control the disease is incompletely defined. Especially, for etanercept, data are lacking. On the basis of our recent study, an adalimumab trough concentration of $1 \mu \mathrm{g} / \mathrm{mL}$ might be adequate to control TNF blockade. ${ }^{4}$ It is, however, challenging to derive such results from observational studies with fixed-dosed treatment. A considerable number of patients with low concentrations is required to define the threshold adequate concentration, which are unavailable in the clinical setting.

Furthermore, individual bDMARDs should be studied separately, because pharmacokinetic aspects differ substantially. For instance, the half-life time for an antibody (eg, adalimumab) is about 21 days, assuming no antidrug antibodies, versus 3 days for the TNF receptor antagonist (etanercept). With pharmacokinetic modelling, an algorithm can be developed to determine individualised dose reduction based on drug concentrations.

In conclusion, we welcome the study of Marotte et al in the field of TDM. We expect that determination of critical concentrations and development of algorithms based on pharmacokinetic modelling will further contribute to the use of TDM in the treatment of rheumatic diseases.

\footnotetext{
Merel J I'Ami ๑ , ${ }^{1}$ Charlotte L Krieckaert, ${ }^{1}$ Michael T Nurmohamed, ${ }^{1,2}$ Ronald F van Vollenhoven, ${ }^{2}$ Theo Rispens, ${ }^{3}$ Maarten Boers $\odot{ }^{2,4}$ Gerrit Jan Wolbink ${ }^{1,3}$

${ }^{1}$ Rheumatology, Amsterdam Rheumatology and Immunology Center | Reade, Amsterdam, The Netherlands
}

${ }^{2}$ Amsterdam Rheumatology and Immunology Center | Amsterdam Medical Center, VU Medical Center, Amsterdam, The Netherlands

${ }^{3}$ Immunopathology, Sanquin Research and Landsteiner Laboratory, Amsterdam, The Netherlands

${ }^{4}$ Epidemiology and Biostatistics, VU University Medical Center, Amsterdam, The Netherlands

Correspondence to Merel J I'Ami, Amsterdam Rheumatology and Immunology Center | Reade, Amsterdam 1104 LP, The Netherlands; m.lami@reade.nl

Handling editor Josef S Smolen

Contributors MJA, CLK, MTN, TR, RFvV, MB and GJW prepared and edited the manuscript, and decided to submit the letter for publication.

Funding This research has received no specific grant from any funding agency in the public, commercial or not-for-profit sectors.

Competing interests MJA has no conflicts of interest to report. CLK has received honoraria for lectures from Pfizer. MTN has received research funding or speaking/ consultancy honoraria from AbbVie, Pfizer, Merck, Roche, BMS, UCB, Eli Lilly, Celgene and Janssen. RFvV has received research support and grants from AbbVie, Amgen, BMS, GSK, Pfizer, Roche and UCB, and honoraria for consultancy from AbbVie, Biotest, BMS, Celgene, Crescendo, GSK, Janssen, Lilly, Merck, Novartis, Pfizer, Roche, UCB and Vertex. TR has received honoraria for lectures from Pfizer, AbbVie and Regeneron, and a research grant from Genmab. MB has received consultancy from Pfizer, BMS, UCB and Teva. GJW has received research funding from Pfizer and honoraria for lectures and in advisory boards of Pfizer, UCB, BMS, AbbVie, Novartis and Biogen.

Patient consent for publication Not required.

Provenance and peer review Commissioned; internally peer reviewed.

(c) Author(s) (or their employer(s)) 2020. No commercial re-use. See rights and permissions. Published by BMJ.

\section{Check for updates}

To cite I'Ami MJ, Krieckaert CL, Nurmohamed MT, et al. Ann Rheum Dis 2020;79:e82.

Received 3 May 2019

Accepted 3 May 2019

Published Online First 9 May 2019

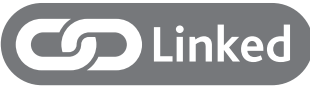

- http://dx.doi.org/10.1136/annrheumdis-2019-215546

Ann Rheum Dis 2020;79:e82. doi:10.1136/annrheumdis-2019-215609

ORCID iDs

Merel J l'Ami http://orcid.org/0000-0001-9584-1088

Maarten Boers http://orcid.org/0000-0002-6969-283X

\section{REFERENCES}

1 Marotte H, Rinaudo-Gaujous M, Petiet C, et al. Tapering without relapse in rheumatoid arthritis patients with high TNF blocker concentrations: data from STRASS study. Ann Rheum Dis 2020;79:e81.

2 I'Ami MJ, Krieckaert CLM, Nurmohamed MT, et al. Successful reduction of overexposure in patients with rheumatoid arthritis with high serum adalimumab concentrations: an open-label, non-inferiority, randomised clinical trial. Ann Rheum Dis 2018;77:484-7.

3 Fautrel B, Pham T, Alfaiate T, et al. Step-down strategy of spacing TNF-blocker injections for established rheumatoid arthritis in remission: results of the multicentre noninferiority randomised open-label controlled trial (STRASS: Spacing of TNF-blocker injections in Rheumatoid Arthritis Study). Ann Rheum Dis 2016;75:59-67.

4 Berkhout LC, I'Ami MJ, Ruwaard J, et al. Dynamics of circulating TNF during adalimumab treatment using a drug-tolerant TNF assay. Sci. Transl. Med. 2019;11:eaat3356. 